\title{
Is transabdominal ultrasound scanning of cervical measurement in mid-trimester pregnancy a useful alternative to transvaginal ultrasound scan?
}

\section{Orta-trimester gebelikte servikal ölçüm için transabdominal ultrason tarama transvajinal ultrason taramaya karşı yararlı bir alternatif midir?}

\author{
Kalyansree Chaudhury ${ }^{1}$, Mrinalkanti Ghosh ${ }^{2}$, Atin Halder ${ }^{1}$, Sourav Senapati ${ }^{3}$, Sudeshna Chaudhury ${ }^{4}$ \\ 'Department of Obstetrics and Gynecology, Burdwan Medical College, Burdwan, India \\ ${ }^{2}$ Department of Radiodiagnosis, Burdwan Medical College, Burdwan, India \\ ${ }^{3}$ Department of Gynecology, Kharagpur Subdivisional Hospital, Kharagpur, India \\ ${ }^{4}$ Department of Ultrasonography, The Birth Assisted Conception Institute, Kolkata, India
}

\section{Abstract}

Objective: The aim of this study is to assess the correlation between transabdominal and transvaginal ultrasound measurements of the cervix in pregnancy. If transabdominal ultrasound measurement of cervical length is found to provide effective information, it could be used in patient counselling and when making clinical decisions.

Material and Methods: One hundred and twenty seven pregnant patients between 18-26 weeks of pregnancy were enrolled in this prospective study for measuring cervical length, both by transabdominal and transvaginal ultrasound scan after bladder emptying. Transabdominal and transvaginal measurements were compared and correlated.

Results: In patients with transvaginal ultrasound scan (TVS) cervical length $\leq 32 \mathrm{~mm}$, TVS cervical length was found to be shorter than by transabdominal ultrasound scan (TAS). Most of these patients needed $>3 \mathrm{~cm}$ of vertical pocket of urine in the bladder for adequate visualisation of the cervix. In patients with TVS cervical length $>32 \mathrm{~mm}$, the TVS measurement of the cervix was longer than the TAS measurement of the cervix. In these patients, the cervix could be seen by TAS when there was either $\leq 3 \mathrm{~cm}$ vertical pocket of urine in the bladder or an empty bladder. Statistical tests showed that there is a significant difference between TAS and TVS cervical measurements and that there is a significant association between these two measurements.

Conclusion: Most of the patients needed variable degrees of bladder filling for adequate visualisation of the cervix. Although minimal bladder filling does not influence TAS measurements of cervical length, moderate fullness of the bladder does cause an apparent increase in TAS measurements of cervical length. If the cervical length is $\geq 30 \mathrm{~mm}$ by TAS, regardless of urine content in the bladder, the patient can be assured vis a vis their risk of preterm labour as far as cervical length is concerned. However, in patients with TAS cervical measurement $<30 \mathrm{~mm}$ and where the bladder needed a moderate amount of urine for adequate visualisation of the cervix, TVS cervical measurement may be close to the critical value of $25 \mathrm{~mm}$. These patients need to be counselled and offered TVS for better assessment of cervical length. (J Turkish-German Gynecol Assoc 2013; 14: 225-9)

Key words: Cervical length, transabdominal sonography, transvaginal sonography

Received: 10 July, 2013

\section{Özet}

Amaç: Bu çalışmanın amacı, gebelikte serviksin transabdominal ve transvajinal ultrason ölçümleri arasındaki korelasyonu değerlendirmektir. Eğer servikal uzunluğun transabdominal ultrason ölçümü etkin bilgi sağlarsa, hastaya rehberlik ve klinik karar vermede kullanulabilir.

Gereç ve Yöntemler: Gebeliğin 18-26. haftaları arasındaki 127 hamile hasta mesane boşaltımı sonrası hem transabdominal hem de transvajinal ultrason taraması ile servikal uzunluk ölçümü için bu prospektif çalışmaya dahil edildi. Transabdominal ve transvajinal ölçümler karşılaştırıldı ve korelasyonlarına bakıldı.

Bulgular: Transvajinal ultrason taraması (TVS) ile servikal uzunluğu $\leq 32 \mathrm{~mm}$ olan hastalarda, TVS servikal uzunluk transabdominal ultrason taraması (TAS)'ndakine göre daha kısa bulundu. Bu hastaların çoğunda, serviksin yeterli görüntülenmesi için mesanede $>3 \mathrm{~cm}$ 'lik vertikal idrar cebi gerekliydi. TVS serviks uzunluğu $>32 \mathrm{~mm}$ olan hastalarda, serviks TVS ölçümü serviks TAS ölçümünden daha uzundu. Bu hastalarda mesanede $\leq 3 \mathrm{~cm}$ vertikal idrar cebi olduğunda ya da boş bir mesane varlığında serviks TAS ile görülebildi. İstatistiksel testler TAS ve TVS servikal ölçümleri arasında önemli bir fark olduğunu ve bu iki ölçüm arasında anlamlı bir ilişki olduğu gösterdi.

Sonuç: Hastaların çoğunda serviksin yeterli görüntülenmesi için çeşitli derecelerde mesane dolumu gerekliydi. Minimal mesane dolumunun servikal uzunluk TAS ölçümlerini etkilememesine rağmen, mesanenin orta derece dolgunluğu servikal uzunluk TAS ölçümlerinde belirgin bir artışa neden olmaktadır. Servikal uzunluk TAS ile $\geq 30$ $\mathrm{mm}$ ise, mesanedeki idrar içeriğine bakmaksızın, servikal uzunluk söz konusu olduğu sürece hastanın erken doğum riski ile karşı karşıya olduğundan emin olunabilir. Bununla birlikte, TAS serviks ölçümü $<30 \mathrm{~mm}$ olan hastalarda ve serviksin yeterli görüntülenmesi için mesanede orta derecede idrar miktar gerekli olduğunda, TVS servikal ölçümü 25 mm'lik kritik değere yakın olabilir. Bu hastalara danışmanlık gerekir ve servikal uzunluğun daha iyi değerlendirilmesi için TVS önerilir. (J Turkish-German Gynecol Assoc 2013; 14: 225-9)

Anahtar kelimeler: Servikal uzunluk, transabdominal sonografi, transvajinal sonografi

Geliş Tarihi: 10 Temmuz $2013 \quad$ Kabul Tarihi: 14 Ağustos 2013 


\section{Introduction}

Prematurity remains a major cause of perinatal morbidity and mortality $(1,2)$. Two-thirds of all preterm births are due to preterm labour with or without the rupture of membranes (3). This makes the identification of patients who are at risk of preterm labour and the prevention of prematurity a very important area for study. It is this area where cervical sonography can make a difference. The measurement of cervical length provides an accurate prediction of risk for early preterm delivery (4).

Transvaginal ultrasound scan (TVS) measurement has become the preferred method and is the only ultrasound technique that has been validated in the prediction of spontaneous preterm birth (5). Although TVS is the method that is generally recommended for assessing cervical length in women at high risk of preterm birth, many women in our culture either decline or are not happy to have a TVS during pregnancy.

A series of papers have showed convincingly that transabdominal ultrasound scan (TAS) measurement of the cervix also has utility in the evaluation of women who are at risk for preterm labour (6). Unfortunately, the use of TAS has a number of pitfalls, such as the fact that although filling of the maternal bladder helps with the visualisation of the cervix, excessive bladder filling reportedly spuriously elongates the length of the cervix (7).

As TVS measurement of the cervix needs training and experience and many women in our culture decline to have a TVS during pregnancy, we were interested in investigating whether TAS measurement of the cervix could be used as an effective alternative for TVS measurement. If it is found that TAS has a predictive correlation with TVS measurements of the cervix, it can be effectively employed in patients' counselling.

The aim of this study is to evaluate the correlation between transabdominal measurement of the cervix with that of transvaginal measurement in pregnant women between 18 and 26 weeks of pregnancy.

\section{Material and Methods}

Institutional Ethics Committee approval was obtained and this prospective study was conducted between October 2012 and May 2013.

For the purpose of this study, women with a singleton pregnancy, no prior history of cervical operation, including cone biopsy or Large Loop Excision of Transformation Zone (LLETZ), and without a cervical cerclage in situ, between 18-26 weeks of gestation were offered enrolment; a total of 127 pregnant patients were recruited following their informed consent.

TAS was done first in the supine position after the patient had emptied her bladder. Thereafter, TVS was done after voiding again, if necessary.

A curvilinear 3.5 Mega Hertz ( $\mathrm{MHz}$ ) transducer was used for transabdominal scan. Transabdominal cervical measurement was obtained with the transducer in the sagittal plane. Bladder filling was noted. The maximum vertical urine pocket in the bladder was measured at the time of TAS. This was done to quantify the amount of residual urine in the bladder. When the cervix was visualised transabdominally, the probe was adjusted to bring the outline of cervical corpus in sight as well as to demonstrate the length of the cervical canal. Cervical length was measured by placing the callipers at the furthest points where the cervical canal walls were juxtaposed.

A $5 \mathrm{MHz}$ vaginal transducer was used for TVS. The patient emptied her bladder prior to the scan if necessary. The patient was placed in the Lloyd-Davies position to allow easy access to the perineum and easy manipulation of the probe without causing any discomfort to the patient. The Transvaginal (TV) probe was inserted slowly until the cervix was clearly visualised in the sagittal plane with echogenic endocervical mucosa along the length of the canal. The probe was then gently withdrawn until the image blurred, and then reinserted, making sure to avoid excessive pressure. The image was sufficiently enlarged to allow clear identification of the echogenic endocervical mucosa, which was used as a guide to identify the internal os to avoid confusion with the lower segment endometrium. Measurement of the cervical length was taken from the internal os to the external os, incorporating only that length which was bordered by endocervical mucosa.

All of the scans were done by one of the three experienced sonographers who standardised the technique as described on 10 cases initially; the data of these cases were not included in this study. In each instance, both transabdominal and transvaginal scans were obtained by the same sonographer.

All of the measurements were taken in triplicate and the shortest best measurement was recorded for final analysis.

\section{Statistical analysis}

A sample size calculation was performed which indicated that 113 patients would be required to detect a $3 \mathrm{~mm}$ difference between transabdominal and transvaginal cervical length, with a power of $80 \%$ and an $\alpha$ error of 0.05 . The tests were 2 -sided, and statistical significance was defined as $\mathrm{p}<0.05$.

Paired ' $\mathrm{T}$ ' test was used to detect the significance of the difference between transabdominal and transvaginal ultrasound measurements. Correlation coefficient was calculated to determine the strength of association between transabdominal and transvaginal measurements.

\section{Results}

Both TAS and TVS were performed on 127 pregnant women between 18-26 weeks of gestation. The mean age of the women was $21.80 \pm 2.46$ years (19-31yrs). $44 \%$ were primigravidae. The mean gestational age was $24.23 \pm 3.83$ weeks (18-26 wks). The minimum and maximum TVS measurements of the cervix were noted to be $22.4 \mathrm{~mm}$ and $55.2 \mathrm{~mm}$, respectively. The transvaginal scan measurements were classified into centiles: $25^{\text {th }}, 50^{\text {th }}$ and $75^{\text {th }}$ centile values of the transvaginal measurements of the cervix were $30.8 \mathrm{~mm}, 36.9 \mathrm{~mm}$ and $43.9 \mathrm{~mm}$, respectively (Table 1).

\section{Relation between TAS and TVS on cervical length}

In patients with up to $25^{\text {th }}$ centile value, where most of the patients needed $>3 \mathrm{~cm}$ vertical pocket of urine in the bladder for adequate visualisation of the cervix, TAS measurement of 
Table 1. Transvaginal scan measurements (in $\mathrm{mm}$ ) in centiles

\begin{tabular}{|l|c|c|c|c|c|}
\hline \multirow{2}{*}{ Transvaginal scan measurements (mm) } & \multicolumn{5}{|c|}{ Centile } \\
\cline { 2 - 6 } & Minimum & $\mathbf{2 5}^{\text {th }}$ & $\mathbf{5 0}^{\text {th }}$ & $\mathbf{7 5}^{\text {th }}$ & Maximum \\
\hline
\end{tabular}

Table 2. The Mean \pm Standard Error (S.E) of all the 'paired differences' with their statistical significance

\begin{tabular}{|l|l|l|l|}
\hline $\begin{array}{l}\text { Centile } \\
\text { (based on TVS measurement) }\end{array}$ & $\begin{array}{l}\text { Mean }( \pm \text { SE) of all the differences } \\
\text { between each paired observations } \\
\text { by both TAS and TVS (TAS minus TVS) }\end{array}$ & p value & Remark \\
\hline Up to $25^{\text {th }}$ Centile & $3.07 \pm 0.80 \mathrm{~mm}$ & $<0.001$ & Significant \\
\hline$>25^{\text {th }}$ to $\leq 50^{\text {th }}$ Centile & $-2.36 \pm 1.24 \mathrm{~mm}$ & $<0.001$ & Significant \\
\hline$>50^{\text {th }}$ to $\leq 75^{\text {th }}$ Centile & $-2.68 \pm 0.29 \mathrm{~mm}$ & $<0.001$ & Significant \\
\hline$>75^{\text {th }}$ to $100^{\text {th }}$ Centile & $-2.90 \pm 0.33 \mathrm{~mm}$ & $<0.001$ & Significant \\
\hline
\end{tabular}

the cervix was longer (average $3.07 \mathrm{~mm}$ ) than the TVS measurement.

Above the $25^{\text {th }}$ centile value in all other centile groups where the patients had either $\leq 3 \mathrm{~cm}$ vertical pocket of urine in the bladder or an empty bladder, the TAS measurement was shorter than the TVS measurement. In patients between $>25^{\text {th }}$ and $50^{\text {th }}$ centile, TAS was $2.36 \mathrm{~mm}$ less, between $>50^{\text {th }}$ centile and $75^{\text {th }}$ centile value, TAS was $2.68 \mathrm{~mm}$ less, and in patients above the $75^{\text {th }}$ centile, the TAS value was $2.9 \mathrm{~mm}$ less than the TVS measurement.

A paired ' $T$ ' test was used and the difference between TAS and TVS measurements in all centile groups was found to be significant $(\mathrm{p}<0.001)$ (Table 2, Figures 1 and 2).

When the data were analysed on the basis of TVS cervical measurements, the following facts were noted:

- In the patients with TVS cervical length $\leq 32 \mathrm{~mm}$, TVS cervical length was, on average, $2.88 \mathrm{~mm}$ (maximum $4.8 \mathrm{~mm}$ ) less than that by TAS. Most of these patients needed $>3$ $\mathrm{cm}$ of vertical pocket of urine in the bladder for adequate visualisation of cervix; some patients needed up to $5 \mathrm{~cm}$ or occasionally even more.

- In the patients with TVS cervical length $>32 \mathrm{~mm}$, the TVS measurement of the cervix was longer than the TAS measurement. In these patients, the cervix could be seen by TAS when there was either $\leq 3 \mathrm{~cm}$ vertical pocket of urine in the bladder or an empty bladder.

Again, when we analysed the data on the basis of TAS cervical measurements, the following facts were noted:

- In patients whose TAS cervical measurement was $\geq 30 \mathrm{~mm}$ and the bladder needed a moderate amount of urine $(>3$ $\mathrm{cm}$ and even up to $5 \mathrm{~cm}$ of vertical pocket of urine in the bladder) for adequate visualisation of the cervix, TVS measurement of the cervix in these patients, although shorter than the TAS measurement, was longer than the critical value of $25 \mathrm{~mm}$ ( $25 \mathrm{~mm}$ is taken as the cut-off length of the cervix for predicting preterm labour).

- In patients whose TAS cervical measurement was $\geq 30 \mathrm{~mm}$ and the cervix could be seen with either an empty bladder or a bladder containing a minimal amount of urine $(\leq 3 \mathrm{~cm}$ of vertical pocket of urine), TVS cervical measurement was confidently above $25 \mathrm{~mm}$.

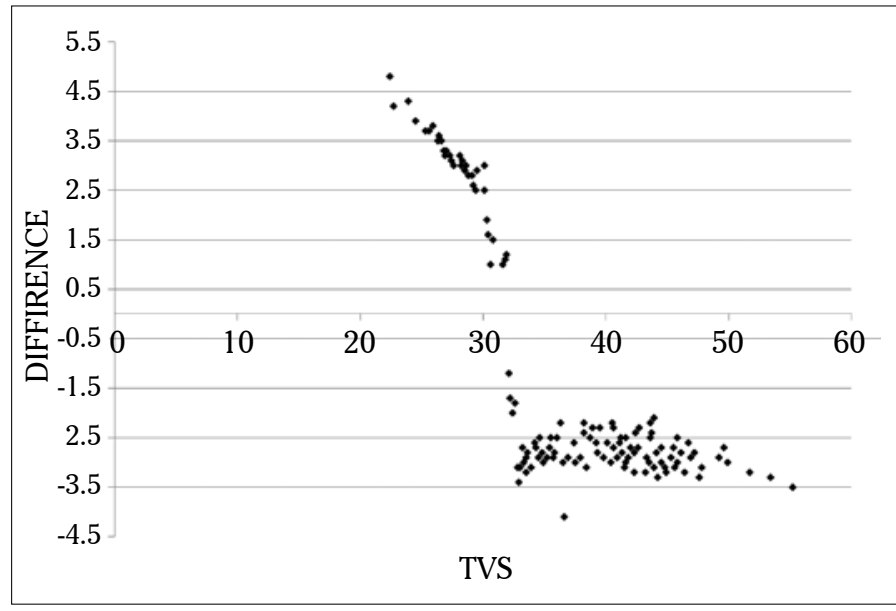

Figure 1. The graph shows the plotting of TAS-TVS differences (in mm on $Y$ axis) against the individual TVS measurements of the cervix (in mm on $\mathrm{X}$ axis)

- In patients whose TAS cervical measurement was $<30$ $\mathrm{mm}$ and the bladder needed a moderate amount of urine ( $>3 \mathrm{~cm}$ vertical pocket of urine in the bladder) for adequate visualisation of the cervix, the TVS cervical measurement was shorter than the TAS measurement and was sometimes close to the critical value of $25 \mathrm{~mm}$.

Although there was a significant difference between transvaginal and transabdominal measurements of cervical length in all of the percentile categories, there was a significant association (correlation coefficient $r=0.96 ; p<0.01$ ) between the two (Figure 3).

\section{Relation between visualisation by TAS and bladder volume}

When the bladder was empty, the cervix could only be adequately visualised by TAS in $17 \%$ of cases. However, the percentage of transabdominal visualisation of the cervix increased as the volume of urine in the bladder increased.

When the bladder had urine with the deepest vertical pocket up to $\leq 3 \mathrm{~cm}$, the cervix could be adequately visualised by TAS in another $61 \%$ of cases.

As the bladder filling increased (up to deepest vertical pocket of $5 \mathrm{~cm}$ or occasionally more), it was possible to visualise the 


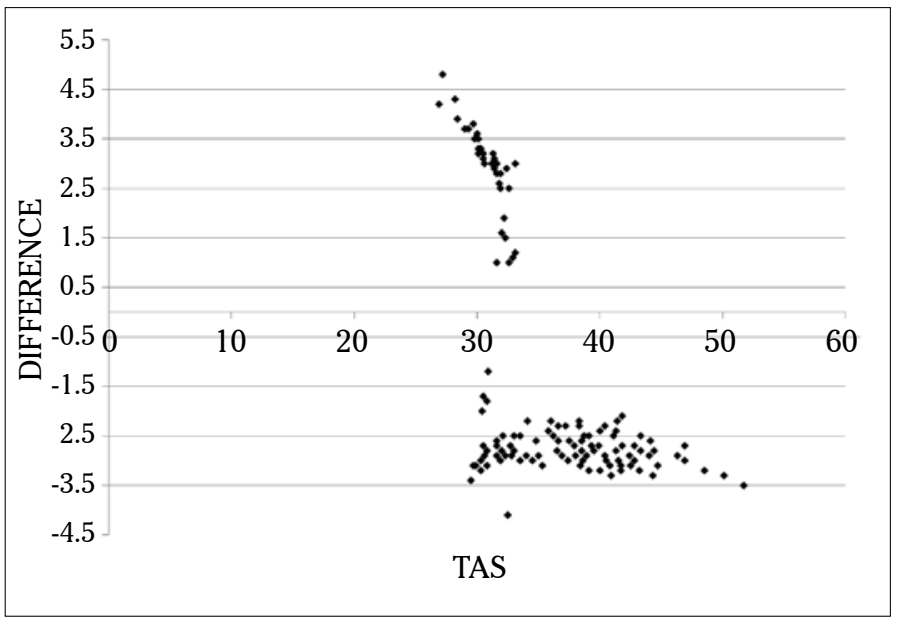

Figure 2. The graph shows the plotting of TAS-TVS differences (in mm on $\mathrm{Y}$ axis) against the individual TAS measurements of the cervix (in $\mathbf{m m}$ on $\mathrm{X}$ axis)

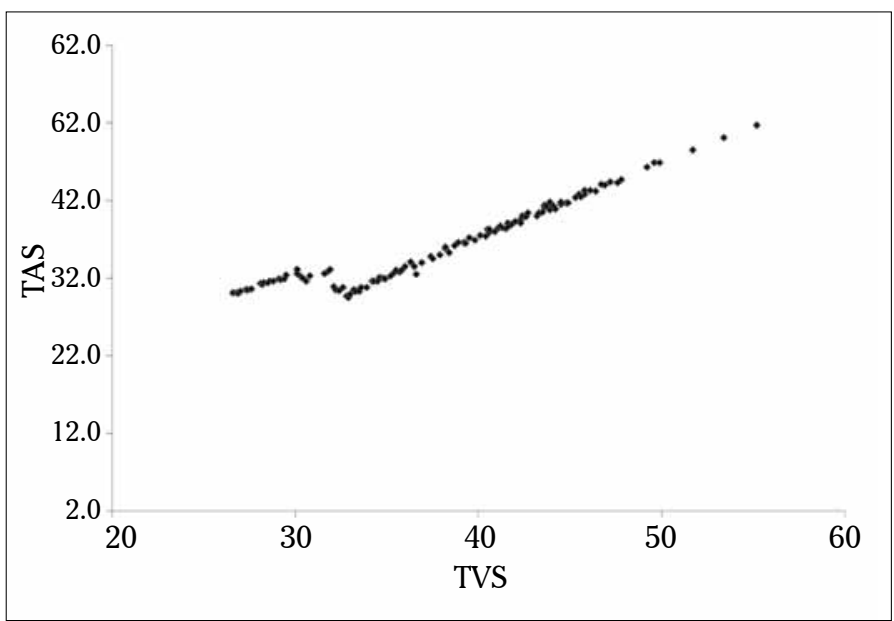

Figure 3. This graph depicts the correlation between transvaginal length (TVS) of the cervix (mm) with that of transabdominal (TAS) length of the cervix ( $\mathrm{mm})$

cervix adequately by transabdominal sonography in the rest of the patients (Figure 4).

Transvaginally, the cervix was satisfactorily visualised in all cases.

\section{Discussion}

There is no need to deny the fact that TVS has several advantages over TAS, simply because of the proximity of the probe to the target organ, i.e. the cervix. However, the technique of TVS has a number of difficulties too. First, the variability of the technique has limited the standardisation of measurements. Second, there is a clear need of training for measurement of the cervix by transvaginal ultrasound (8). Finally, and most importantly in our culture, many patients are not happy to undergo TVS. Patient satisfaction is a key factor in patient care. This consideration has been the principal motivating issue to conduct this study.

The data of this study have demonstrated that in only $17 \%$ of patients was the cervix visible in the presence of an empty

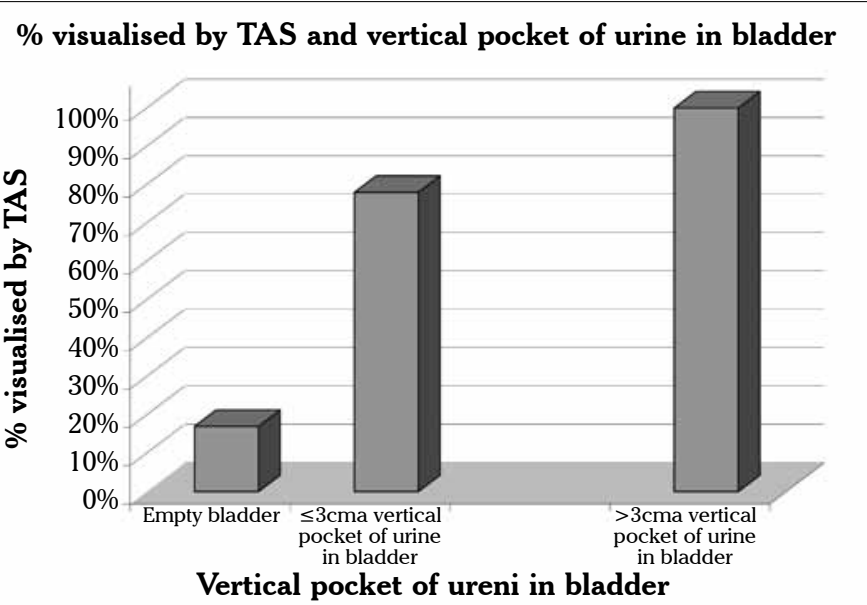

Figure 4. The chart shows the relation between $\%$ visualisation of the cervix by Transabdominal Scan with varying depth pockets of urine in the bladder

bladder by transabdominal sonography. In addition, the cervix could only be seen adequately when there was bladder filling with a vertical pocket of urine of up to $3 \mathrm{~cm}$ or less in $61 \%$ of cases. As the bladder filling increased to a vertical pocket of urine of $5 \mathrm{~cm}$ or occasionally more, it was possible to visualise the cervix adequately by transabdominal sonography in the remaining patients.

The fact that TAS cannot demonstrate the cervix adequately in the presence of an empty bladder in most of the pregnant patients and a variable degree of bladder fullness is required to demonstrate the cervix adequately by TAS is vindicated by the studies of Anderson et al. (7) and To et al. (9).

In this study, we observed that in patients with a TVS cervical length of $\leq 32 \mathrm{~mm}$, TVS cervical length was, on average, 2.88 $\mathrm{mm}$ (maximum $4.8 \mathrm{~mm}$ ) shorter than that by TAS. This observation is consistent with the findings of Saul et al. (10). It is noteworthy that, in this study, most of the patients with TVS cervix length of $\leq 32 \mathrm{~mm}$ needed $>3 \mathrm{~cm}$ of vertical pocket of urine in the bladder for adequate visualisation of the cervix.

The probable explanation of the TAS measurement being longer than that of the TVS lies in the fact that bladder filling causes an increase in cervical length.

A number of studies have established the fact that, although a variable degree of bladder filling has an advantage of improving the visualisation of the cervix in pregnant patients by TAS, it causes artificial lengthening of the cervix $(7,9,11,12)$. This may be explained by the fact that the endocervical mucosa cannot be clearly recognised by TAS (in contrast with TVS where the endocervical mucosa can be recognised clearly) and the internal os is falsely thought to be at a higher level than it actually is in reality. Another explanation (for the apparent increase in cervical length with bladder filling) is that the bladder filling may cause the cervix to be progressively more vertical, which results in apparent measurement changes (13).

In this study, in all other patients with a TVS cervical length of $>32 \mathrm{~mm}$, in general, the cervical length measurement by TAS is shorter than that by TVS. This finding is consistent with the observation by Stone et al. (14), and can also be explained by 
bladder filling. In these patients, the cervix could be visualised by TAS either in an empty bladder or with $\leq 3 \mathrm{~cm}$ vertical pocket of urine in the bladder. Thus, the factor of cervical elongation by bladder fullness was minimal.

Although there is a significant difference in TAS and TVS cervical length, this study finding will be useful in clinical practice. This study has found that if TAS cervical length is $\geq 30 \mathrm{~mm}$ and the bladder is empty or contains a minimal amount of urine $(\leq 3$ $\mathrm{cm}$ vertical pocket of urine), the patient can be assured that the risk of preterm labour is low as far as the cervical length is concerned (because the TVS cervical length is actually longer than the TAS measurement in these patients). Also, in patients with a TAS cervical length $\geq 30 \mathrm{~mm}$, even though there needs to be a moderate amount of urine in the bladder $(>3 \mathrm{~cm}$ up to $5 \mathrm{~cm}$ vertical pocket of urine) for adequate visualisation of cervix, the TVS cervical length is above $25 \mathrm{~mm}$ (taking the critical length of the cervix as $25 \mathrm{~mm}$ ). Hence, these patients can also be assured that their risk of preterm labour is low.

In patients with a TAS cervical length $<30 \mathrm{~mm}$, careful judgement is required, taking bladder fullness in that individual into consideration. In such situations, these patients should be counselled and a transvaginal scan may be offered for the more accurate assessment of cervical length.

In conclusion; a variable degree of bladder filling is necessary for adequate visualisation of the cervix in the large majority of patients.

A minimal amount of bladder filling $(\leq 3 \mathrm{~cm}$ vertical pocket of urine in bladder) does not influence TAS measurements of cervical length. However, with a moderate amount of bladder filling ( $>3 \mathrm{~cm}$ vertical pocket of urine in bladder), TAS measurement of the cervix appears to be longer than the actual measurement. This information is to be kept in mind while making clinical decisions.

In patients whose TAS cervical measurement is $\geq 30 \mathrm{~mm}$, the patient can be assured, regardless of the urine content in their bladder, that the risk of preterm labour is low as far as the cervical length is concerned.

In patients whose TAS cervical measurement is $<30 \mathrm{~mm}$, the patient needs to be counselled and transvaginal scan may be offered for the more accurate measurement of cervical length, particularly when there is a moderate amount $(>3 \mathrm{~cm}$ of vertical pocket of urine) of urine in the bladder.

Ethics Committee Approval: Ethics committee approval was received for the study.

Informed Consent: Informed consent was received from the participants of this study.

Peer-review: Externally peer-reviewed.

Author contributions: Concept - K.C., M.G., S.C.; Design - K.C., A.H.; Supervision - K.C., M.G., S.C.; Resource - K.C., M.G., A.H., S.C.; Materials - K.C., M.G., A.H., S.C.; Data Collection\&/or
Processing - K.C., M.G., S.C.; Analysis\&/or Interpretation - K.C., S.S.; Literature Search - K.C., S.S.; Writing - K.C, S.S.; Critical Reviews - K.C, A.H.

Acknowledgements: The authors would like to thank to Dr. Shyamsundar Mandal for his contributions into the statistical analysis of the study.

Conflict of Interest: The authors declared no conflict of interest.

Financial Disclosure: The authors declared that this study received no financial support.

\section{References}

1. Sonek J, Shellhaas C. Cervical Sonography: a review. Ultrasound Obstet Gynecol 1998; 11: 71-8. [CrossRef]

2. Creasy RK, Gummer BA, Liggins GC. System for predicting spontaneous preterm birth. Obstet Gynecol 1980; 55: 692-5.

3. Arias F, Tomich P. Etiology and outcome of low birth weight and preterm infants. Obstet Gynecol 1982; 60: 277-81.

4. Heath VC, Southall TR, Souka AP, Elisseou A, Nicolaides KH. Cervical length at 23 weeks of gestation: prediction of spontaneous preterm delivery. Ultrasound Obstet Gynecol 1998; 12: 312-7. [CrossRef]

5. Berghella $\mathrm{V}$. Novel developments on cervical length screening and progesterone for preventing preterm birth. Br J Obstet Gynaecol 2009; 116: 182-7. [CrossRef]

6. Brown JE, Thieme GA, Shah DM, Fleischer A, Boehm F. Transabdominal and transvaginal endosonography: evaluation of the cervix and lower uterine segment in pregnancy. Am J Obstet Gynecol 1986; 155: 721-6. [CrossRef]

7. Anderson HF. Transabdominal and transvaginal ultrasonography of the uterine cervix during pregnancy. J Clin Ultrasound 1991; 19: 77-83. [CrossRef]

8. Vayssière C, Morinière C, Camus E, Le Strat Y, Poty L, Fermanian J, et al. Measuring cervical length with ultrasound: evaluation of the procedures and duration of a learning method. Ultrasound Obstet Gynecol 2002; 20: 575-9. [CrossRef]

9. To MS, Skentou C, Cicero S, Nicolaides KH. Cervical assessment at the routine 23 - weeks' scan: problems with transabdominal sonography. Ultrasound Obstet Gynecol 2000; 15: 292-6. [CrossRef]

10. Saul LS, Kurtzman, J T, Hagemann C, Ghamsary M, Wing DA. Is Transabdominal Sonography of the Cervix After Voiding a Reliable Method of Cervical Length Assessment? J Ultrasound Med 2008; 27: 1305-11.

11. Bowie JD, Andreotii RF, Rosenberg ER. Sonographic appearance of the uterine cervix in pregnancy: the vertical cervix. AJR 1983; 19: 77-83.

12. Podobink M, Bulic M, Smiljanic N, Bistricki J. Ultrasonography in the detection of cervical incompetency. J Clin Ultrasound 1988; 13: 383-91. [CrossRef]

13. Mason GC, Maresh MJA. Alterations in bladder volume and the appearance of the cervix. Br J Obstet Gynecol 1990; 57: 457-8.

14. Stone PR, Chan EHY, Mccowan LME, Taylor RS, Mitchell JM. Transabdominal scanning of the cervix at the 20-week morphology scan: Comparison with transvaginal cervical measurements in a healthy nulliparous population. Aust N Z J Obstet Gynaecol 2010; 50: 523-7. [CrossRef] 